year. The Institute for Scientific Information (ISI) is sponsoring with ACRL the Samuel Lazerow Fellowship for outstanding contributions to acquisitions or technical services in an academic or research library. The award, presented for the first time at Annual Conference in Los Angeles, will provide practicing librarians a fellowship for research, travel, or writing.

A second award co-sponsored by ISI is the ACRL Doctoral Dissertation Fellowship. The purpose of this fellowship is to foster research in academic librarianship by encouraging and assisting doctoral students with their dissertation research. It too was awarded for the first time in Los Angeles.

\section{What Lies Ahead}

It should not require an accurate psychic to foresee our immediate future. The economy might be rebounding, but it is going very slowly, and higher education is not one of the growth areas in that economy. As a profession we will have to find better and more compelling ways to articulate our contributions to our parent institutions and to the public at large. We need to identify and delete those activities done by tradition alone, and focus on and communicate those that have the highest payoff to our profession. Librarians cannot be all things to all people; we must use our resources judiciously. Most importantly, we need to be sure that the choices we have made are relevant to the perceived needs of our users and our funding agencies.

The Association of College and Research Libraries needs to make those same decisions, so that we can continue to serve and advance our profession wherever the economy may lead.

\title{
Humanities Programs for Libraries: An ACRL/NEH Workshop
}

\section{Paula Elliot \\ Humanities Reference Librarian Kansas State University}

April on the shores of Lake Mendota, Wisconsin, was its own season, 'mid winter and spring, and a low gray sky wrapped the Yahara Center in a comfortable isolation. The setting was entirely conducive to the activity of the ACRL/NEH workshop on humanities programming, where librarians and humanists gathered to learn from the experts, and from each other, the ways in which the National Endowment for the Humanities makes funds available for library programs. Twenty-five institutions were represented (in most cases) by an academic librarian and a faculty humanist. They met with experienced consultants and NEH representatives for two days of discussion and practice, which focused on the writing of grant proposals to enhance and promote libraries' humanities holdings.

The workshop was the last of a series of four made possible by the National Endowment for the Humanities. The first two were held in late 1981 and early 1982, in Massachusetts and California, respectively (the latter was reported on by George Eberhart in C $\triangleleft R L$ News, May 1982, pp. 169-72). Following their successful completion, ACRL resubmitted its proposal for two additional workshops, which were funded by a grant for $\$ 62,423$, and were held this year in New Orleans and Madison.

The gracious and informal setting of the Yahara Center established the friendly atmosphere for the conference. Librarians and their humanist teammates were barely distinguishable one from another. It was initially entertaining to try to guess which of a pair was the librarian, but it soon became refreshingly evident that such a distinction was unimportant. A collaborative spirit, sometimes missed on our own campuses, was greatly evident. Participants introduced themselves to the group by relating what special interest had brought each team to the workshop. Concerns ranged from public policy to regional history, women's studies to musical comedy. Many came to the workshop with programs in mind, and were eager for information on implementation. All were committed to the promotion of the humanities; all recognized the vital worth of public programming.

The workshop director was Peggy O'Donnell, Chicago library consultant, who coupled her own experience at grant writing with organizational and teaching skills to produce a combination of lectures, panel discussions, and role-playing. Opening the first session with the assurance that "Money is available," she went on to describe the work of the NEH as a funding agency for programs aimed at the out-of-school adult public. Grant applications have diminished due to inflated rumors of budget cutbacks. ACRL staff on hand were Sandy Whiteley, program officer, and Barbara Macikas, continuing education officer. Their advance planning and on-the-spot coordinating efforts moved events along smoothly.

Huel Perkins, assistant vice-chancellor for academic affairs, Louisiana State University, deliv- 
ered a rousing address vindicating the preservation and the promotion of the humanities in American life. He reminded his audience that, unlike the sciences, the study of the humanities is "not so much an increase in knowledge as an increase in insight," and that both are essential to the survival of democracy. A grant-writing veteran, he further contributed his perceptions of the process, along with Jessie Smith and Gregory Stevens. Smith, as director of the Fisk University Library, Nashville, successfully implemented the NEH-funded program, "Themes in the Black American Experience," which provided three years of cultural events to the Nashville and Fisk University communities. Stevens, as director of the Capital District Humanities Program, administers NEH funds in a variety of educational offerings, in the Albany, New York, region.

In the absence of program officer Tom Phelps, Abbie Cutter represented the Endowment. Cutter, whose $\mathrm{NEH}$ specialty is the museum program, presented an overview of NEH grant opportunities for libraries. She then spoke specifically about the criteria for a stong proposal, emphasizing clarity at every juncture. She noted that it is important to define explicitly a program theme, target audience, resource people, and use of library resources. All panelists reiterated this admonition. From the Wisconsin Humanities Council, executive director Pat Anderson provided a view of humanities programming at the state level. Her contribution placed state activities in the larger context of the $\mathrm{NEH}$, and provided some ideas for smaller-scale programs which librarians might develop with state funds.

After absorbing many suggestions and caveats from the panelists, participants were ready to go to work themselves. Each participant was assigned to a small group which represented a planning committee. A staff member assisted, and a recorderreporter was chosen. When presented with a written description of a certain academic library situation (e.g., large urban, community college, small rural), each group's collective imagination blossomed.

It was the task of the group to devise a librarybased program highlighting certain special collections which were outlined in the description. Though the written descriptions were moderately detailed, participants, warming to the task, relished the opportunity to embroider each situation to suit their fancies. Some witty exchanges occurred. What also occurred, as the session progressed, was a deepening seriousness, and a genuine response to the panelists' suggestions. In the group with the philospher present, the incisive question constantly arose: "Does this idea, this proposed program, this theme, have real humanistic value?" The refrain was crucial. (A by-product of the group sessions was a taste of the committee experience with its attendant accords and difficulties.) Halfway through the planning process, the groups reported to one another and to the "NEH"-as played by the panel of experts-for feedback and suggestions.

At this point not one proposal was considered fundable, although all were promising. Hearing about one another's process gave fuel to the second group session, where revisions and refinements were made. Upon a second reporting, the hypothetical situations had become richly embellished, and great care had been taken to justify the humanities content of every program. Lectures interspersing the group sessions included one on the utilization of faculty humanist consultants in the planning stages, and another on budgeting the proposal. After a third group session, in response to the improvements, the panel expressed the possibility of funding each group's project. For a majority of participants, this simulation technique provided an excellent opportunity to discover the planning process, and to reinforce information heard earlier from the panel.

Another amenity of the workshop was the evening time spent in conversation, over ample refreshments, in the homey Yahara lounge. Workshop staff were available to discuss individual programming concerns. Also in these moments, participants could exchange ideas and compare notes, coming away from the workshop richer not only for the intended contents, but also for that

\section{NEH Offers Program Development Grants}

The National Endowment for the Humanities has announced that the next deadline for applications for a program development grant is August 1, 1983, for any project beginning after April 1, 1984. Project applications must be received at the Endowment's offices by the established deadline date. Future application deadlines are February 6,1984 , for projects beginning after October 1, 1984; and August 6, 1984, for projects beginning after April 1, 1985.

$\mathrm{NEH}$ encourages proposals in the following areas: 1) the history, theory, and criticism of the arts; 2) the interpretation of literature; and 3 ) the 200th anniversary of the U.S. Constitution. Academic or research libraries considering public programs in any of these areas are eligible to apply. Lectures, discussions, conferences, films, short radio broadcasts, small interpretive exhibits, theatrical productions, and essays in newspapers have all been tested and evaluated in previous NEH-funded projects.

To receive a complete set of guidelines and application forms, call or write the NEH Office of Special Projects, 1100 Pennsylvania Avenue, N.W., Washington, DC 20506; (202) 7860271 . 
glimpse of a larger professional world which such a meeting inherently offers. It is safe to speculate that, NEH-funded or not, many new program ideas are likely to be tried at the libraries of those institutions represented in Madison.

The April workshop was the last ACRL/NEH event on humanities programming for academic li- braries. Related programs are envisioned for the future, but these are still in the proposal stage. The previous workshops all emphasized the accessibility of the National Endowment for the Humanities, and encouraged librarians to utilize existing public funds in order to bring their public the humanistic experience.

\section{The Librarian As Library User:}

\section{A Personal Comment}

\section{Mina Jane Grothey \\ Ibero-American Reference Librarian University of New Mexico}

We librarians speak fervently about our goal to serve the users of our libraries. Yet how many of us are library users ourselves, both of our own library and other libraries in our community? If we are library users, do we utilize our experiences to make our libraries easier to use? Too often the attitude is, "If I can find it, why can't they?" We have forgotten how much trouble we had the first time we tried to find the same thing.

For the past few years I have been doing research on liberation theology in Latin America. My primary goal has been to discover the best sources for locating current English-language materials on the subject. As a reference librarian, I could feel comfortable on both sides of the desk. I had not realized the difference between my attitude to the library as a librarian and as a user until, when checking a list of promising articles, I found myself muttering, "We don't have any of the good journals." I stopped and chuckled as I remembered how many times I had heard users saying the same thing!

From behind the desk my reply was always sympathetic as I suggested that a user request articles through interlibrary loan. From in front of the desk I felt the same frustration, maybe even more so. Since I knew the state of the serials budget, I also knew that the chances of adding to the collection were very slim. Even if we did add the journals now, we could not afford the backfiles containing those great articles from two years ago.

Do I always take the time to explain the limitations of interlibrary loan? For example, how long it takes to fill a request or the fact that some items may not be loaned at all. Our library has begun a procedure whereby we will request items for undergraduates through interlibrary loan, not only if they have a note from their professor, but also if they get the signature of a reference librarian. This procedure has made me much more aware of the importance of speaking to users about their needs before sending them to interlibrary loan. There is always a chance that the library might own something that will help but the user knows nothing about it.

I had always thought of myself as a library user as well as a librarian. I have used and supported the local public library in communities where I have lived. This use has been for recreational reading and as an alternate source for general information. Now I realize that finding out what other libraries in the area have in their collections and what services they provide can aid me in making referrals.

When I worked on a subject master's degree a few years after completing my MLS, I was amazed at how much easier it was for me to complete assignments requiring use of the library. Just understanding the basics of how a library functions was a great asset, although this headstart did not eliminate all the problems. In fact I ended up giving informal library instruction to my classmates.

This instruction helped me to realize that knowing how to use the library and really using it can be two different things. Just being aware of the filing rules for the card catalog is a great advantage. Knowing that cards can be misfiled or the title card can be missing should make it a routine procedure to go that little bit farther in searching for a book. Do I always carry this knowledge over when helping a user?

As a librarian I usually don't hesitate to ask if I need help in finding something. With others this is not always the case. A commonly acknowledged problem is how to create an atmosphere around the reference desk that welcomes questions. One aspect of this problem I have encountered is that the work I do at the desk will create the impression that I am too busy to be bothered. On the other hand, just sitting and waiting for questions gives the impression that I don't have enough work to do. Being aware of people in the area and watching for signs that they need help takes a conscious effort that goes a long way toward creating an appropriate atmosphere.

One of the most popular library cliches says that library instruction has the greatest impact on a person who needs it the most. The same principle 